\title{
Egusi Melon-Okra Intercrop: Yield Effects as Influenced by the Interaction of Time of Introducing Okra x Cropping Systems at Makurdi, Nigeria
}

\author{
Michael Ojore ljoyah ${ }^{1 *}$, Felix Terna Fanen ${ }^{2}$, Moses Onyilo Egbe ${ }^{1}$ \\ ${ }^{1}$ Department of Crop Production, University of Agriculture, P.M.B. 2373, Makurdi, Nigeria \\ ${ }^{2}$ Department of Crop Production Technology, Akperan Orshi College of Agriculture, Yandev, \\ Nigeria
}

*E-mail address: mikejoy2005@yahoo.com

Keywords: cropping systems; time of planting; egusi melon; okra; Nigeria.

\begin{abstract}
A field experiment was conducted from August to November, during the 2012 and 2013 cropping seasons at the Research Farm, University of Agriculture, Makurdi, Nigeria, to evaluate the yield effects of egusi melon-okra intercrop as influenced by the interaction of time of introducing okra $\mathrm{x}$ cropping systems, and to assess the yield advantages of the intercropping system. The experiment was a $3 \times 3$ split plot arrangement of treatments, fitted in a randomized complete block design (RCBD), replicated four times. The cropping systems (sole egusi melon, sole okra and egusi melon-okra mixture) constituted the main plots, while the time of introducing okra (mid August, late August and early September) into egusi melon were allocated to the subplots. Results of study showed that to obtain optimal intercrop yield of okra in an egusi melon-okra intercrop, it is appropriate planting okra at the same time with egusi melon in mid August, while introducing okra into egusi melon in late August is appropriate to obtain optimal intercrop yield of egusi melon. Intercropping egusi melon and okra significantly $(\mathrm{P} \leq 0.05)$ reduced yields of egusi melon $(37.5 \%$ and $40.5 \%$ respectively, in years 2012 and 2013$)$ and that of okra $(9.7 \%$ and $16.9 \%$ respectively, in years 2012 and 2013). The highest mean land equivalent ratio value of 1.57 and highest land equivalent coefficient values of 0.53 and 0.70 were respectively recorded, in years 2012 and 2013, for okra introduced into egusi melon in early September. These recommendations are appropriate for Makurdi location, Nigeria.
\end{abstract}

\section{INTRODUCTION}

Okra (Abelmoschus esculentus L. Moench) originated in Asia and Africa and belongs to the family Malvaceae (Absar and Siddique, 1992). It is a semi-woody, fibrous, herbaceous annual plant with an indeterminate growth habit (Balock, 1994), and is regarded as one of the important vegetable crop grown in tropical and subtropical parts of the world (Christo and Onuh, 2005). World production of okra as fruit vegetable is estimated at 6 million tonnes per year, but in West Africa, it is estimated at 500,000 to 600,000 tonnes per year (Burkil, 1997). In Nigeria, okra ranked third in relation to consumption and production area, following tomato and pepper (Ibeawuchi, 2007). The crop is rich in both minerals and proteins which are both vital to man's growth and development and used by different people in different ways (Katung and Kashina, 2005). The immature pods are consumed as boiled vegetable and are also dried and used as soup thickeners or in stews (Yadev and Dhanker., 2002). Foliage of okra plants are known to provide good sources of fodder for livestoch (BOSADP, 1998). The mucilage preparation from the immature pod is used medicinally in the treatment of ulcers and in the reliefs of hemorrhoids (Yadev and Dhanker, 2002). Egusi melon (Citrullus lunatus, Thunb) is a member of the family Curcurbitaceae (Badifu and Ogunsa, 1991). It originated from Africa, later introduced to Europe and Asia during the last 2000 years (Tindal, 1986). The world production of melon seeds in year 2002 was reported at 576,000 tonnes from 608,000 hectares (Brisibe et al., 2011). There has been a tremendous increase in the production of egusi melon, especially in Nigeria where it is cultivated over an area of 361,000 hectares with seed yield of about 347,000 tonnes per annum, probably because of the increased awareness of its economic value (Badifu and Ogunsa, 1991). The crop is popular in the country for 
its edible seed which contains approximately $40 \%$ oil, $28 \%$ protein and some important minerals (Ogbonna and Obi, 2010). The highly prized vegetable oil extracted from the seed is of high nutritional value, composed mainly of unsaturated fatty acids, which gives a unique flavor to foods during cooking (Ogbonna and Obi, 2010).

A number of studies have been conducted on monocropped egusi melon and okra as affected by time of planting, aimed at improving yields of the sole crops (Muoneke and Asiegbu, 1997; Ijoyah et al., 2010), however, these studies did not reveal the appropriate time of introducing okra, particularly in an egusi melon-okra intercrop. In addition, there is paucity of scientific information on the yield performance of egusi melon and okra under different cropping systems. An investigation was therefore undertaken with the objective of identifying the appropriate time of introducing okra into egusi melon, that will produce optimal yields of egusi melon-okra intercrop as well as the yield response of component crops to different cropping systems.

\section{MATERIALS AND METHODS}

\subsection{Meteorological information of site and physico-chemical properties of soil}

The meteorological information for Makurdi during the growth period from August to November, in years 2012 and 2013 is presented in Table 1. Rainfall was regular from the months of August to October, with a corresponding relative humidity. In both years, the month of September recorded the highest amount of rainfall and the highest number of rainy days, while the average solar radiation was about 6.0 hours during the growth period of the component crops. Soil samples were collected from different parts of the experimental field. The composite sample was used to determine the physical and chemical properties of the soil before planting (Table 2). Total nitrogen value was low, ranging from $0.07 \%$ and $0.14 \%$ for both years. The soil had a medium level of available phosphorus with a corresponding low level of potassium, ranging from $0.19 \%$ and $0.23 \%$ for both years. The $\mathrm{pH}$ in water was near neutral, while that in salt was slightly acidic (Table 2).

\subsection{Crop varieties, experimental design, treatment allocation and planting}

The okra variety 'NH47-4' was obtained from the National Institute for Horticultural Research and Training (NIHORT), Ibadan, Nigeria, while the egusi melon 'Itchier Udam' is a local variety, popularly grown by farmers in the locality. The varieties of both crops show good adaptation to Makurdi environment.

The experiment was a $3 \times 3$ split plot arrangement of treatments, fitted in a randomized complete block design, and replicated four times. The cropping systems, which consisted of sole egusi melon, sole okra and egusi melon-okra intercrop were allocated to the main plots, while the time of introducing okra into egusi melon (okra sown at the same time with egusi melon in mid August, okra introduced 2 weeks later in late August into egusi melon, and okra introduced 4 weeks later in early September into egusi melon) were assigned to the subplots. The experimental area cultivated was $418.5 \mathrm{~m}^{2}$ and consisted of 36 subplots. Each subplot had an area of $9.0 \mathrm{~m}^{2}$. The experimental field was cleared, ploughed and harrowed. Each plot consisted of 4 ridges. In sole egusi melon plot, each ridge consisted of 8 egusi melon stands, at an intra-row spacing of $35 \mathrm{~cm}$ (Okaka and Remison, 1999). A total of 32 egusi melon stands were sown in each plot. In sole okra plot, 10 okra stands were planted on each ridge, at an intra-row spacing of $30 \mathrm{~cm}$ (Ijoyah et al., 2010), giving a total of 40 okra stands per plot. In the sole plots, egusi melon and okra were planted in a single row, on top of the ridge, at their recommended time of planting, while in the intercrop plots, egusi melon was sown in a single row on top of ridge, while okra was sown by the side of the ridge, and at the varied time of introductions. Two egusi melon and two okra seeds were sown at a depth of $2-3 \mathrm{~cm}$ and later thinned to one plant per stand at two weeks after planting (WAP). 


\subsection{Cultural practices and harvesting}

Weeding was done as the need arose. The recommended rate for mixed fertilizer NPK (15:15:15) for sole okra at the rate of $100 \mathrm{~kg} \mathrm{ha}^{-1}$ as described by Ekpete (2000), for sole egusi melon: mixed fertilizer NPK $(15: 15: 15)$ at the rate of $120 \mathrm{~kg} \mathrm{ha}^{-1}$, and for egusi melon-okra intercrop: mixed fertilizer at the rate of $120 \mathrm{~kg} \mathrm{ha}^{-1}$ (Enwezor et al., 1989). Harvesting of okra was done when the tip of pod was observed to break easily when pressed with the finger tip (Usman, 2001). Egusi melon was harvested at 16 WAP, when the leaves turned yellowish and fallen off with stem drying, which were signs of senescence and crop maturity (Ijoyah et al., 2012).

\subsection{Data collected and analysis}

Data collected on okra included days to attain $50 \%$ flowering (taken by counting the number of days from when crop was sown to when $50 \%$ flowered), plant height (measured in $\mathrm{cm}$ as the distance from the soil surface to the tip of the top most leaf), leaf area (measured in $\mathrm{cm}^{2}$ as described by Breda, (2003), using the length-width method: LXW, where L is the leaf length and W is the largest width of the leaf). The number of leaves, number of branches and number of pods per plant were obtained from a sample of 4 plants in each plot and averaged. The pod length and pod diameter were also measured in $\mathrm{cm}$. Fresh okra was harvested and weighed for pod weight in grams and total pods for each net plot area were also harvested and weighed for total yield (kg) converted to $\mathrm{tha}^{-1}$.

Data collected for egusi melon included days to attain $50 \%$ flowering, number of branches per plant, number of leaves per plant, leaf area, number of fruits per plant, number of seeds per fruit, seed weight $(\mathrm{g})$ and yield $\left(\mathrm{t} \mathrm{ha}^{-1}\right)$. Analysis of variance (ANOVA) for split plot design was carried out on each observation and the Least significant difference (LSD) was used for means separation $(\mathrm{P} \leq 0.05)$ following the procedure of Steel and Torrie (1980). Direct treatment effects and the magnitude of interactions were also determined.

\subsection{Evaluation of intercropping advantages}

The land equivalent ratio (LER) was determined as described by Willey (1985) using the formula:

$L E R=\frac{\text { Intercrop yield of crop } A}{\text { Sole crop yield of } A}+\frac{\text { Intercrop yield of crop } B}{\text { Sole crop yield of } B}$

The competitive ratio (CR) as described by Willey and Rao (1980) was determined using the formula:

$C R=L m / L o$, where; $L m$ : Partial LER for egusi melon; $L o$ : Partial LER for okra.

The percentage (\%) land saved as described by Willey (1985) using the formula:

$\%$ land saved $=100-1 /$ LER $X 100$

Aggressivity(A) gives a simple measure of how much the relative yield increase in component ' $a$ ' is greater than that for component ' $b$ ' as described by McGilchrist (1971) using the formula:

$A=\frac{\text { Mixture yield of }{ }^{\prime} a^{\prime}}{\text { Expected yield of }{ }^{\prime} a^{\prime}}-\frac{\text { Mixture yield of }{ }^{\prime} b^{\prime}}{\text { Expected yield of }{ }^{\prime} b^{\prime}}$

Where:

$\mathrm{A}=0$ : indicates that both crops are equally competitive; $\mathrm{A}=-$ : indicates dominated component

$\mathrm{A}=+$ : indicates dominant component

The land equivalent coefficient (LEC) as described by Adetiloye et al., (1983) was determined using the formula:

$L E C=L a \times L b$; where $L a: L E R$ of main crop; $L b: L E R$ of intercrop.

These calculations were used to assess the advantages of the intercropping system. 


\section{RESULTS AND DISCUSSION}

2.1 Main effects of time of introducing okra and cropping systems, and their interaction effects on growth and yields of egusi melon-okra intercrop

The main effect of time of introducing okra and cropping system did not significantly $(\mathrm{P} \leq 0.05)$ affect days to attain $50 \%$ flowering for okra (Table 3), however, as time of introducing okra advanced, days to attain $50 \%$ flowering for okra reduced in both years. The cropping system used, did not significantly $(\mathrm{P} \leq 0.05)$ affect days to attain $50 \%$ flowering for okra (Table 3$)$. Okra plant height significantly $(\mathrm{P} \leq 0.05)$ reduced as time of planting okra advanced (Table 3$)$. This could be due to the progressive decrease in the amount of rainfall and number of rainy days recorded in both years, particularly in the months of September to October. This result agreed with the findings of Ezeakunne (2004) and Ijoyah and Jimba (2012), who reported lower plant height as planting date advanced due to drastic reduction in the amount of rainfall. In both years, intercropping egusi melon and okra significantly $(\mathrm{P} \leq 0.05)$ reduced okra plant height (Table 3$)$. The reduction in okra height under intercropping could have been induced by the intense overcrowding effect of the intercrops compared to sole cropping for available nutrients. This view agreed with that of Madu and Nwosu (2001), who reported that yam planted soles, generally have greater efficiency in utilizing growth environment. Number of branches per plant and number of okra leaves per plant decreased as time of planting okra advanced (Table 3$)$. Intercropping egusi melon and okra significantly $(\mathrm{P} \leq 0.05)$ reduced number of branches and number of okra leaves per plant (Table 3 ). This result agreed with Silwana and Lucas (2002) who reported that intercropping reduced vegetative growth of component crops.

The leaf area of okra, number of pods per plant, pod length and pod width significantly $(\mathrm{P} \leq 0.05)$ reduced as planting dates of okra progressed (Table 4). The reduction in the number of pods per plant as okra planting dates progressed agreed with Turk et al., (2003) who reported that late planting reduced the number of lentil pods per plant. Shad et al., (2010) also reported that the delay in the time of sowing faba bean promoted the reduction in the size of the pods. Okra sown in midAugust gave the highest pod weight and highest yield of $6.2 \mathrm{t} \mathrm{ha}^{-1}$ and $6.4 \mathrm{t} \mathrm{ha}^{-1}$, respectively in years 2012 and 2013 (Table 4). The highest yield obtained from early planted crop could be due to the longer vegetative period and better utilization of water and nutrients. In addition, the largest leaf area and highest number of pods recorded from mid August planting, could have contributed to the highest pod yield obtained. Intercropping egusi melon and okra significantly $(\mathrm{P} \leq 0.05)$ reduced pod yield by $9.7 \%$ and $16.9 \%$ respectively, in years 2012 and 2013, as compared to that obtained from okra sown as a sole crop. This result agreed with those of Olufajo (1992) and Muoneke et al., (2007) who reported higher yield in sole cropping over intercropping.

Planting okra at the same time as egusi melon in mid August significantly $(\mathrm{P} \leq 0.05)$ recorded longer days to attain $50 \%$ flowering for okra (Table 5). Similarly, largest leaf area, highest number of pods, highest pod weight and highest pod yields of $5.3 \mathrm{t} \mathrm{ha}^{-1}$ and $5.0 \mathrm{t} \mathrm{ha}^{-1}$ respectively recorded, in years 2012 and 2013, were produced planting okra at the same time as egusi melon in mid August (Table 6). The high amount of rainfall recorded for the early planting (mid August) could have enhanced a greater absorption of nutrients, which might have influenced a higher pod weight and yield. In addition, the reduced interspecific competition for growth resources at the period of planting okra at the same time with egusi melon could also be linked to the highest pod weight and pod yield obtained.

\subsection{Main effects of time of introducing okra and cropping systems, and their interaction effects on growth and yields of egusi melon-okra intercrop}

Though days to attain $50 \%$ flowering for egusi melon was not significantly $(\mathrm{P} \leq 0.05)$ affected by the okra planting dates, however, intercropping egusi melon and okra significantly $(\mathrm{P} \leq 0.05)$ reduced days to attain $50 \%$ flowering for egusi melon (Table 7). The longer days taken to attain 50 $\%$ flowering for sole egusi melon as compared to intercropped egusi melon contradicted the results of Ijoyah et al., (2012), who reported longer days to attain $50 \%$ flowering for intercropped egusi 
melon in an egusi melon-maize intercrop. The difference in results could be due to the growth habit of component crops, and possibly the arrangement of the component crops in the intercrop.

Planting okra in late August increased number of branches of egusi melon, number of leaves per plant, leaf area of egusi melon (Table 7), number of egusi melon fruits per plant, number of egusi melon seeds per fruit, weight of seeds per fruit and yield of egusi melon (Table 8). Intercropping egusi melon and okra significantly $(\mathrm{P} \leq 0.05)$ reduced yield of egusi melon by $40.5 \%$ and $48.7 \%$ respectively, in years 2012 and 2013, as compared to that obtained from sole egusi melon (Table 8). Although, days to attain $50 \%$ flowering for egusi melon was not significantly $(\mathrm{P} \leq 0.05)$ affected by time of introducing okra, however, highest number of branches of egusi melon, highest number of leaves per plant, largest leaf area (Table 9), highest number of egusi melon fruits per plant and highest yield of egusi melon were obtained introducing okra into egusi melon in late August (Table 10). The lowest yield of egusi melon obtained in both years as planting of okra was done at same time in mid August, could be attributed to the longer shading effect of okra over egusi melon, thereby limiting the phothosynthetic absorption of light, consequently reducing intercropped yield of egusi melon. Introducing okra into egusi melon in late August, gave the highest intercropped yield of egusi melon (2.8 $\mathrm{tha}^{-1}$ and $3.5 \mathrm{t} \mathrm{ha}^{-1}$, respectively in years 2012 and 2013).

\subsection{Intercropping advantages of egusi melon and okra}

Irrespective of the main effects of time of introducing okra and cropping system, total intercrop yields were greater than the sole crops and intercrop yields (Table 11). The land equivalent ratio (LER) values for all treatments at the 2-way interaction of time of introducing okra $\mathrm{x}$ cropping systems were all above 1.0, indicating yield advantage of the intercropping system (Table 12). Average of both years showed that the highest LER of 1.57 was recorded when okra was sown into egusi melon in early September, signifying that it is most advantageous having both crops in intercropping at this interaction level. This could be due to the highest efficiency of resource utilization attained at the treatment level. This level of treatment also recorded an average of $36.1 \%$ of land saved, which could be used for other agricultural purposes. The highest land equivalent coefficient (LEC) values of 0.53 and 0.70 were respectively recorded in years 2012 and 2013 from okra sown into egusi melon in early September (Table 12). Adetiloye et al., (1983) reported that for a two crop mixture, the minimum expected productivity coefficient is $25 \%$. While the lowest competitive ratio (CR) was recorded for okra sown at the same time with egusi melon in mid August, the highest aggressivity was obtained sowing okra into egusi melon in early September, the level at which both crops dominated each other (Table 12).

\section{CONCLUSION}

From the results obtained, it can be concluded that sowing okra at the same time with egusi melon in mid August gave the highest intercrop yield of okra, but the highest intercrop yield of egusi melon was obtained introducing okra into egusi melon in late August. While the lowest competitive ratio (CR) was recorded for okra sown at the same time with egusi melon in mid August, the highest LER, highest LEC and highest aggressivity were obtained introducing okra into egusi melon in early September. 
Table1. Meteorological information for Makurdi, Nigeria(August- November), 2012 and 2013

\begin{tabular}{|c|c|c|c|c|c|}
\hline Year/Months & $\begin{array}{l}\text { Average } \\
\text { monthly rainfall } \\
(\mathrm{mm})\end{array}$ & \multicolumn{2}{|c|}{$\begin{array}{l}\text { Average monthly } \\
\text { temperature }\end{array}$} & $\begin{array}{l}\text { Average relative } \\
\text { humidity } \\
(\%)\end{array}$ & $\begin{array}{l}\text { Average solar } \\
\text { radiation } \\
\text { (hrs) }\end{array}$ \\
\hline 2012 & & Max. & Min. & & \\
\hline August & $237.3(16)^{\circ}$ & 30.0 & 23.0 & 79.8 & 5.9 \\
\hline September & $243.0(18)$ & 29.8 & 22.8 & 79.6 & 5.6 \\
\hline October & $98.7 \quad(9)$ & 31.5 & 22.4 & 73.6 & 6.4 \\
\hline November & $0 \quad(0)$ & 24.2 & 17.5 & 54.2 & 6.4 \\
\hline \multicolumn{6}{|l|}{2013} \\
\hline August & $256.2(12)^{*}$ & 30.5 & 23.1 & 77.4 & 5.6 \\
\hline September & $217.2(15)$ & 31.4 & 21.2 & 77.8 & 6.3 \\
\hline October & $213.3(10)$ & 32.4 & 23.3 & 75.2 & 5.7 \\
\hline November & $0(0)$ & 33.4 & 18.6 & 52.3 & 6.6 \\
\hline
\end{tabular}

* Value in parenthesis indicates number of rainy days.

Source: Air Force Base Makurdi, Meteorological Station. 
Table 2. Physico-chemical properties of the soil of experimental site before planting in years 2012 and 2013.

\begin{tabular}{llll}
\hline Parameters & \multicolumn{2}{c}{ Quantity in Soil } & Method of analysis \\
\cline { 2 - 4 } & 2012 & 2013 & \\
\hline Organic matter & $2.6 \%$ & $1.5 \%$ & Walkley-Black method \\
Nitrogen & $0.14 \%$ (Low) & $0.07 \%$ (Low) & Kjeldahl method. \\
$\mathrm{P}_{2} \mathrm{O}_{5}$ & $10.3 \mathrm{ppm}$ (Medium) & $11.5 \mathrm{ppm}$ (Medium) & Flame photometric \\
$\mathrm{K}$ & $0.23 \%$ (Low) & $0.19 \%$ (Low) & Oxidation method \\
$\%$ Sand & $82.2 \%$ & $81.5 \%$ & Hydrometer meter \\
$\%$ Silt & $7.4 \%$ & $6.9 \%$ & Hydrometer meter \\
$\%$ Clay & $10.4 \%$ & $11.6 \%$ & Hydrometer meter \\
$\mathrm{pH}\left(\mathrm{H}_{2} \mathrm{O}\right)$ & 6.2 & 6.4 & pH meter \\
$\mathrm{pH}\left(\mathrm{Cacl}_{2}\right)$ & 4.5 & 5.5 & pH meter \\
\hline
\end{tabular}

Type of soil: Sandy-Loam

Source: Soil Science Laboratory, University of Agriculture, Makurdi, Nigeria. 


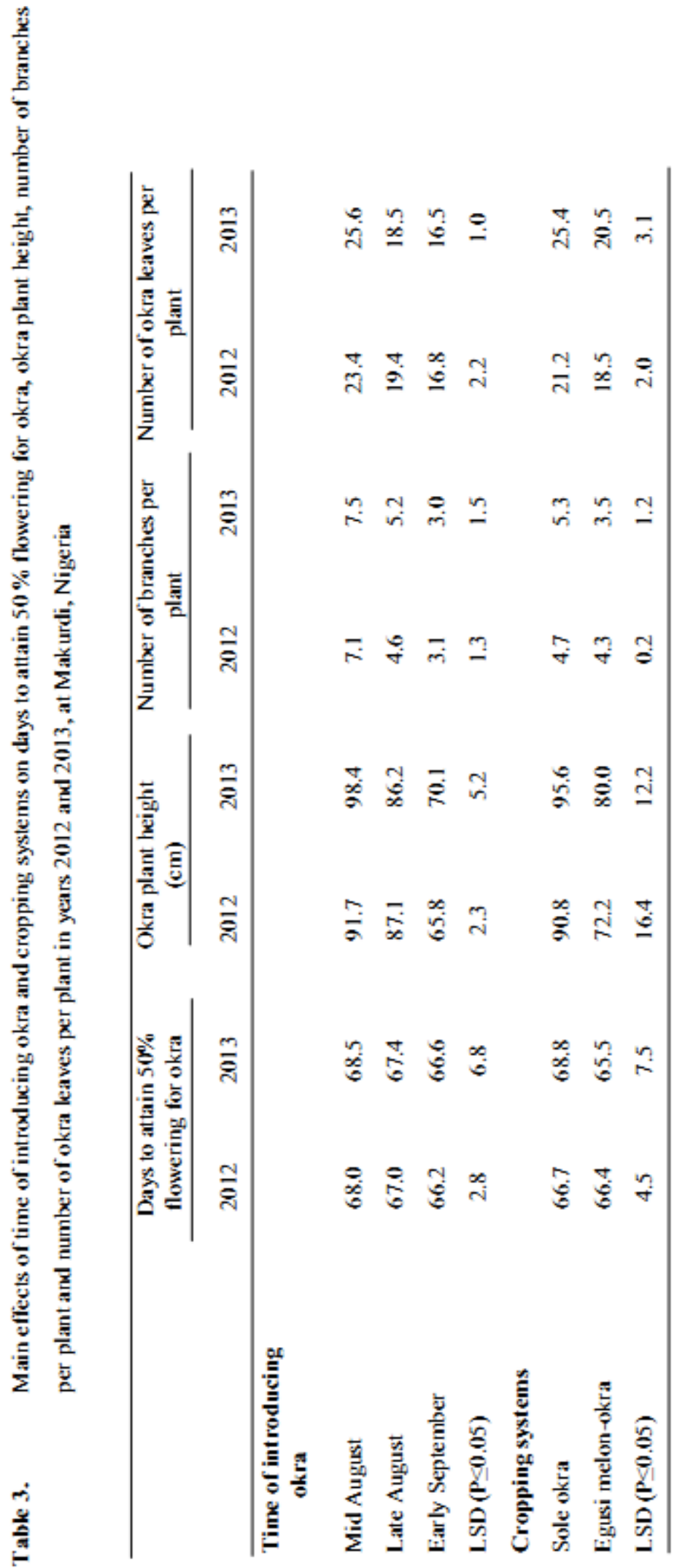




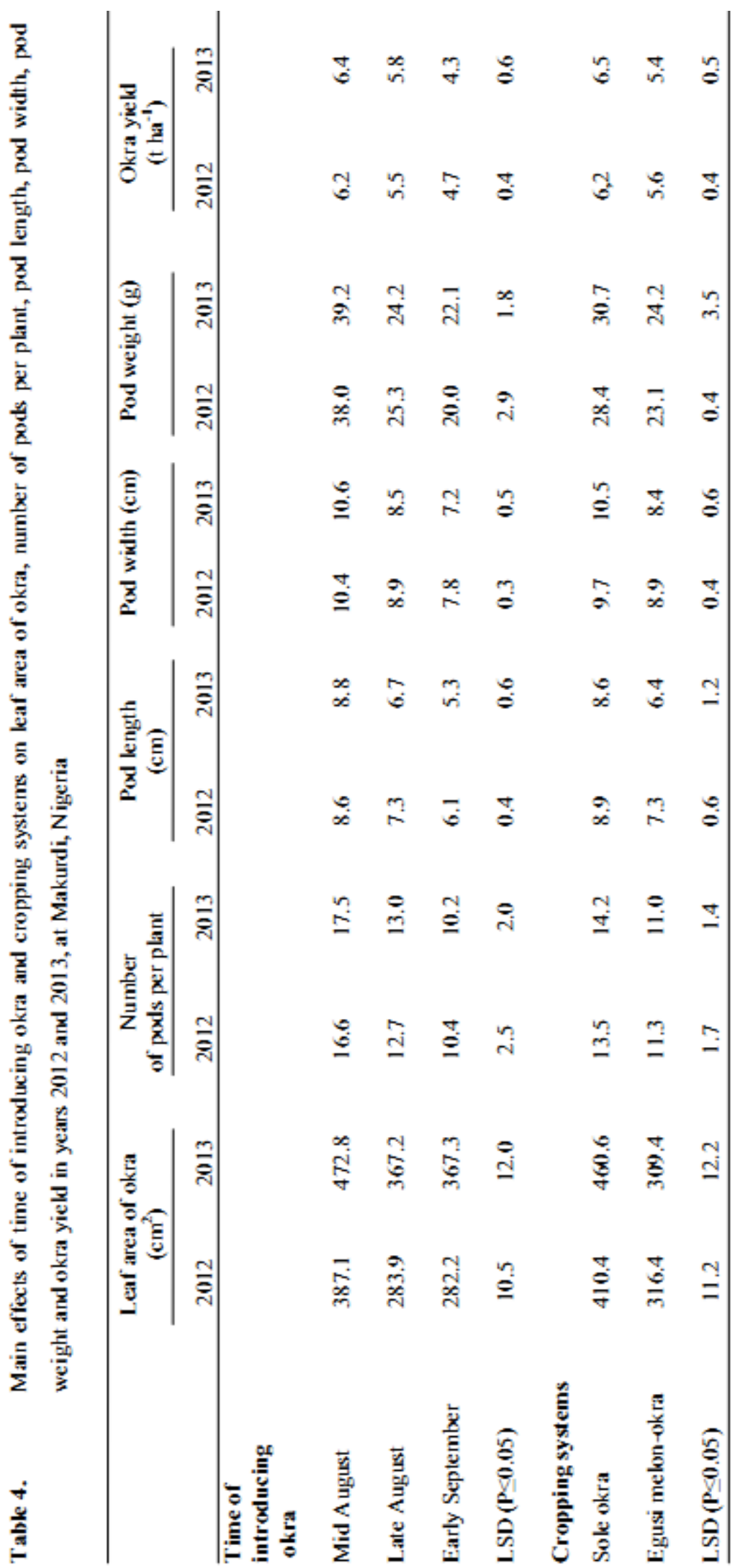




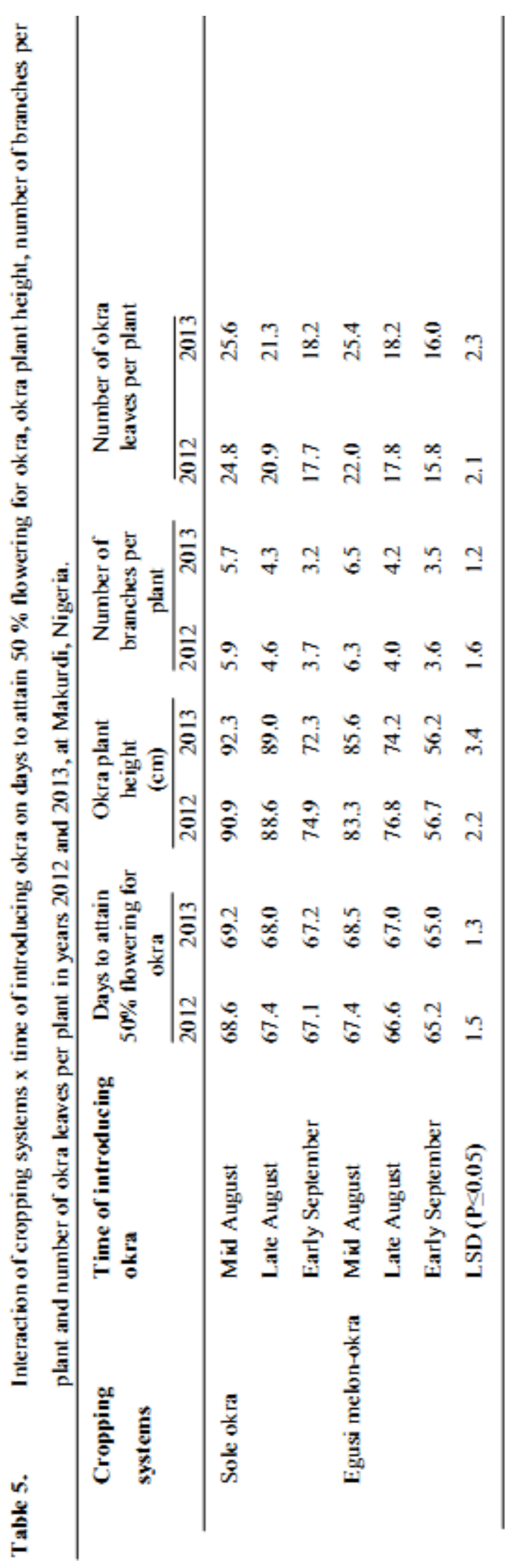




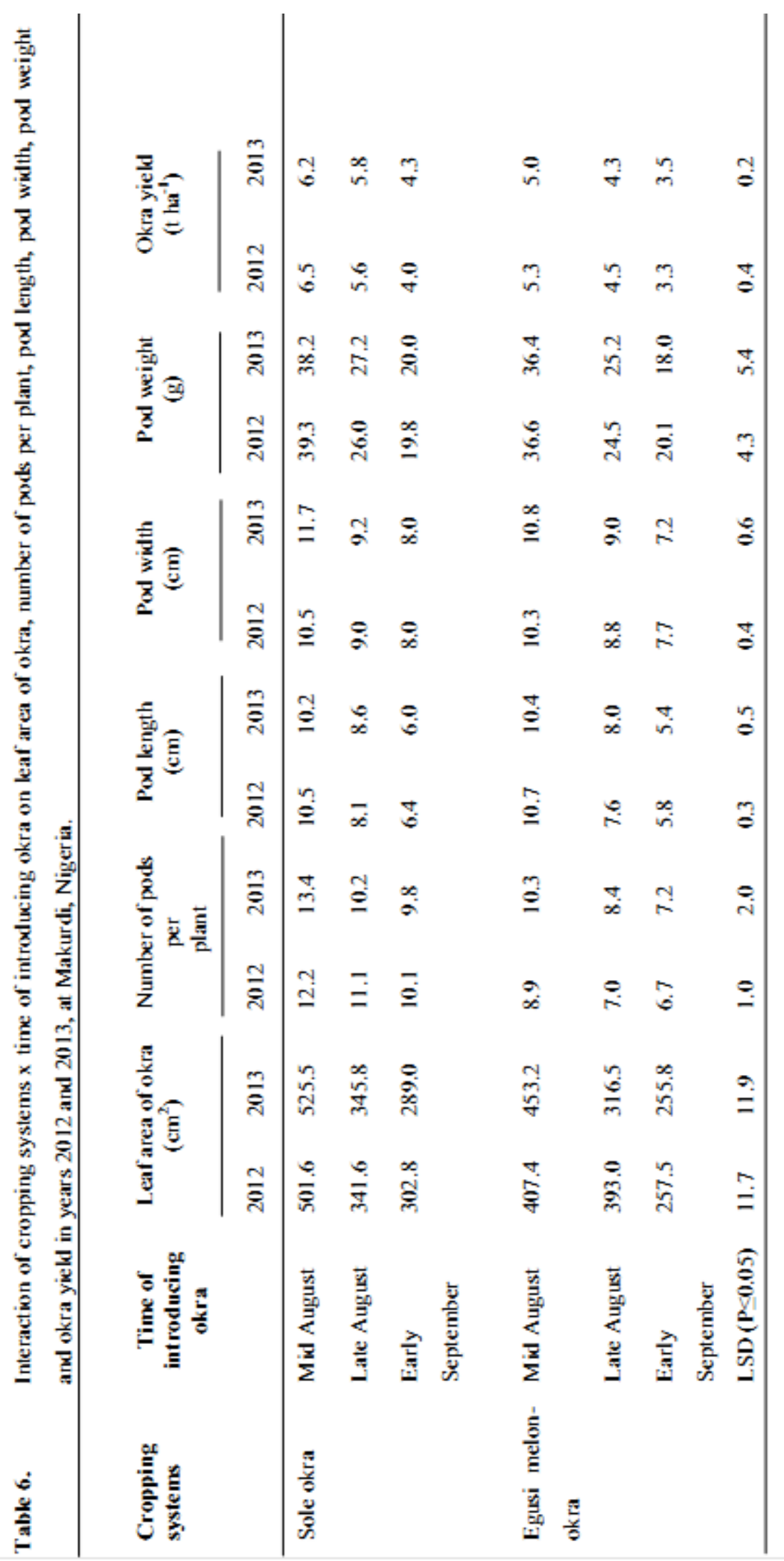




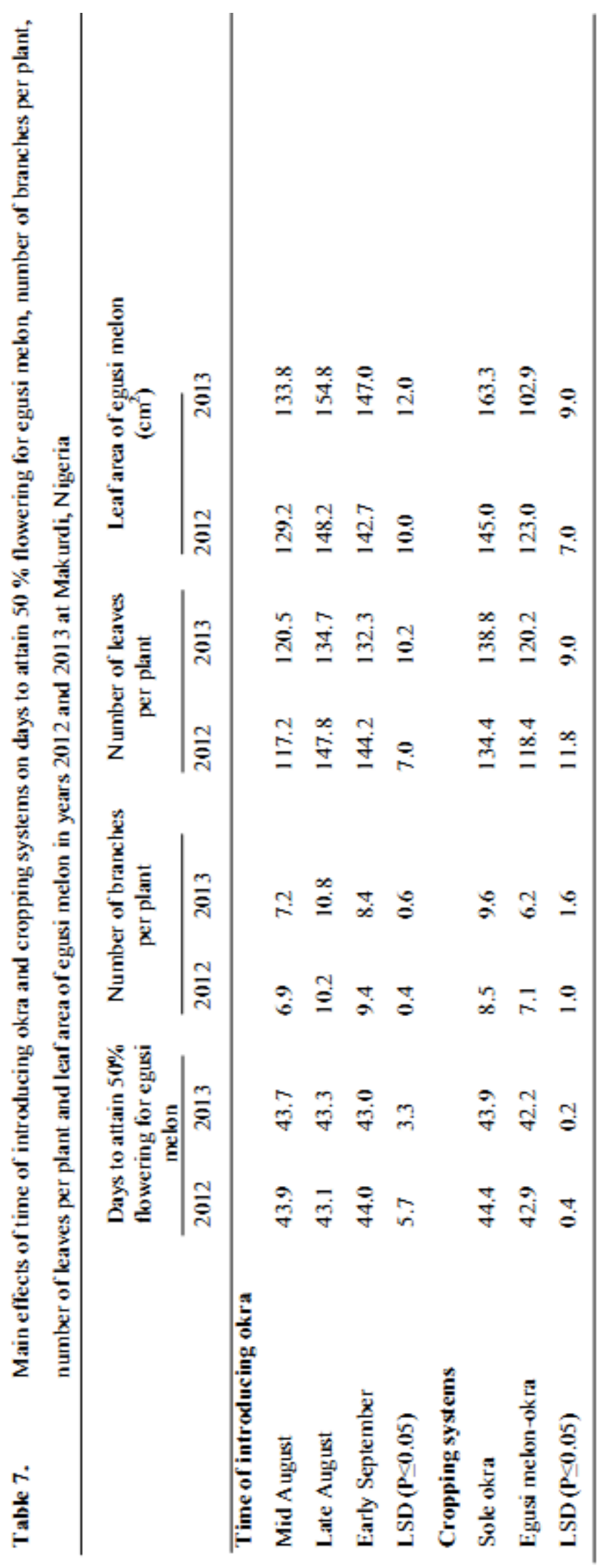




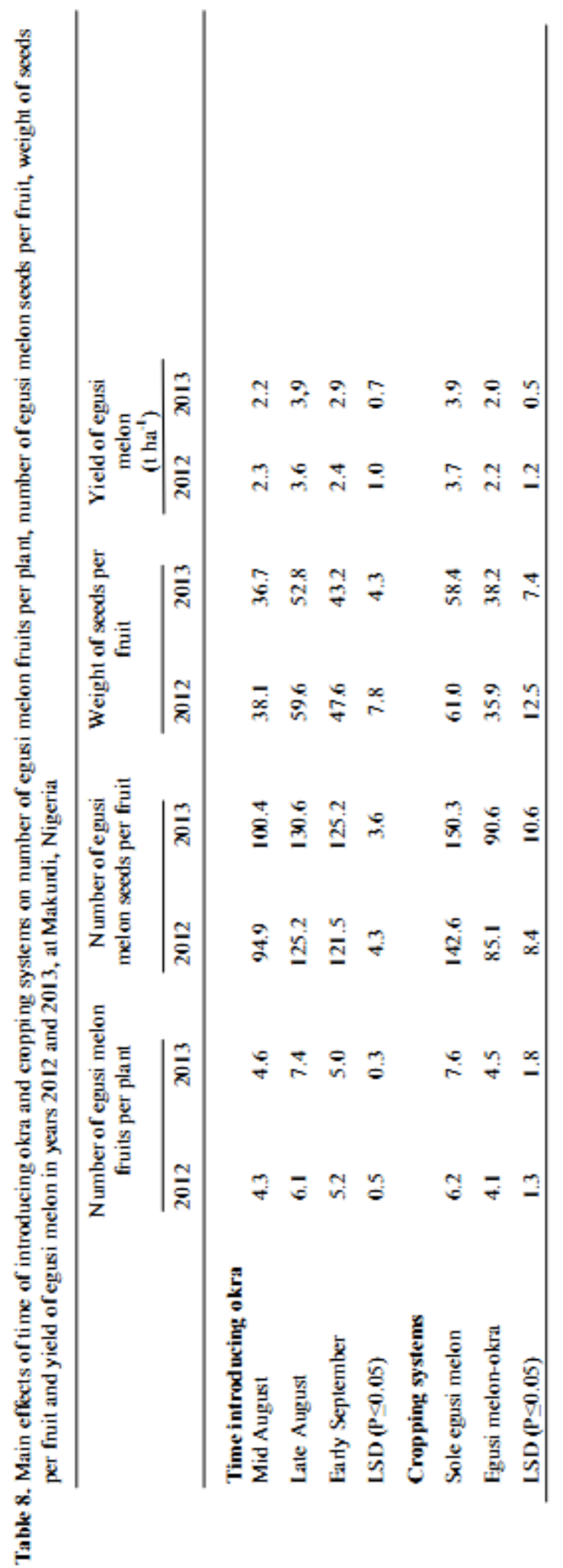




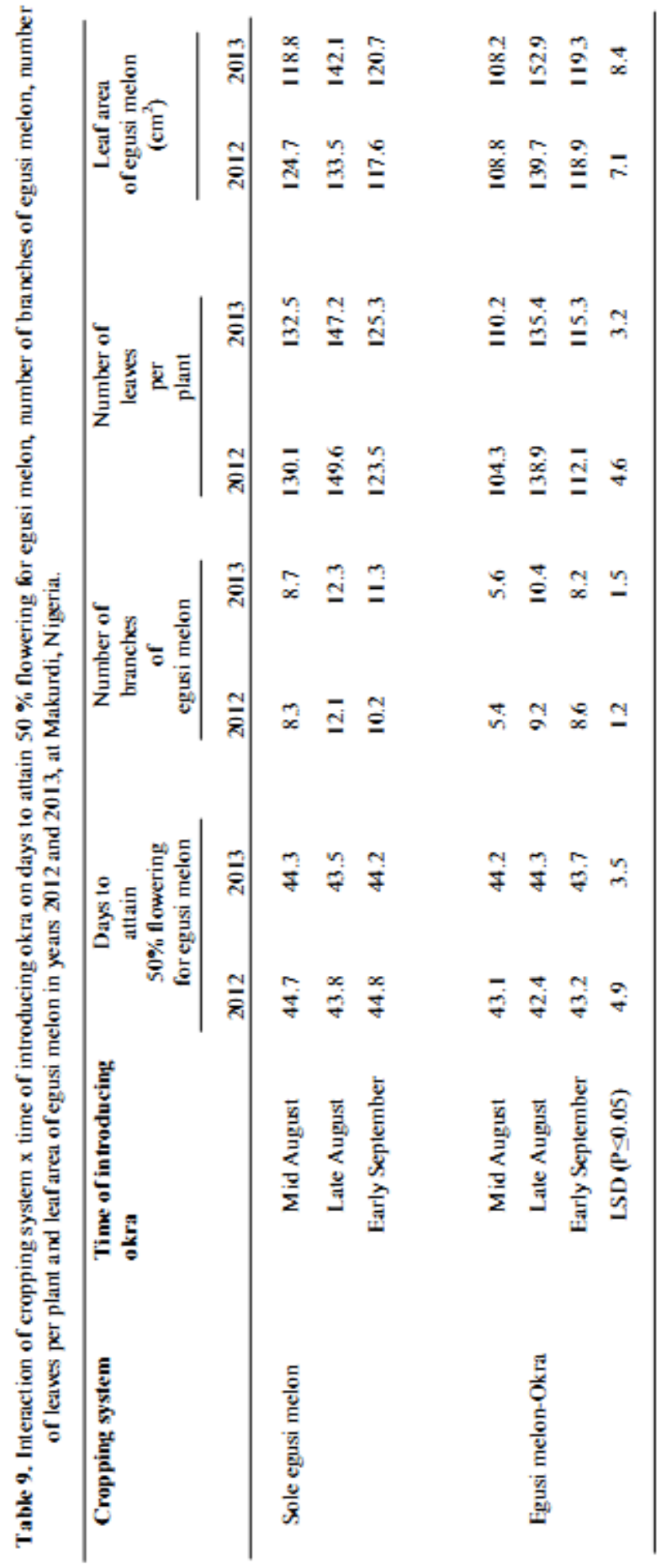




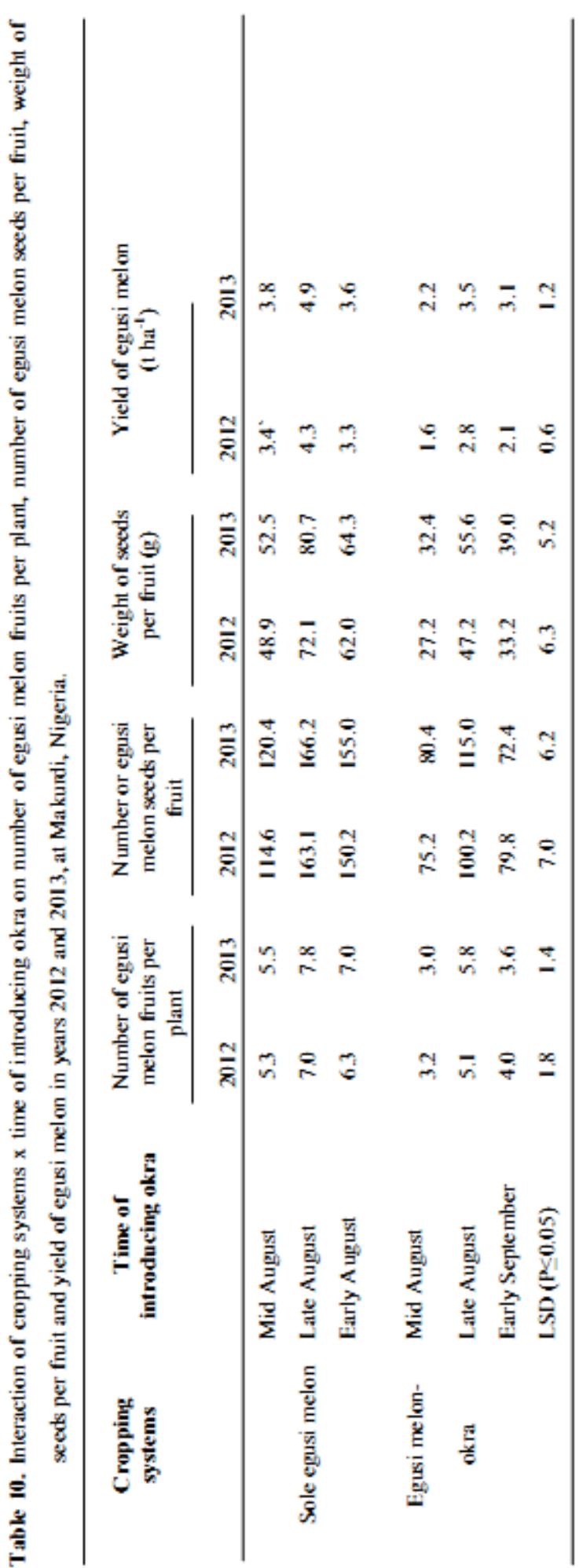




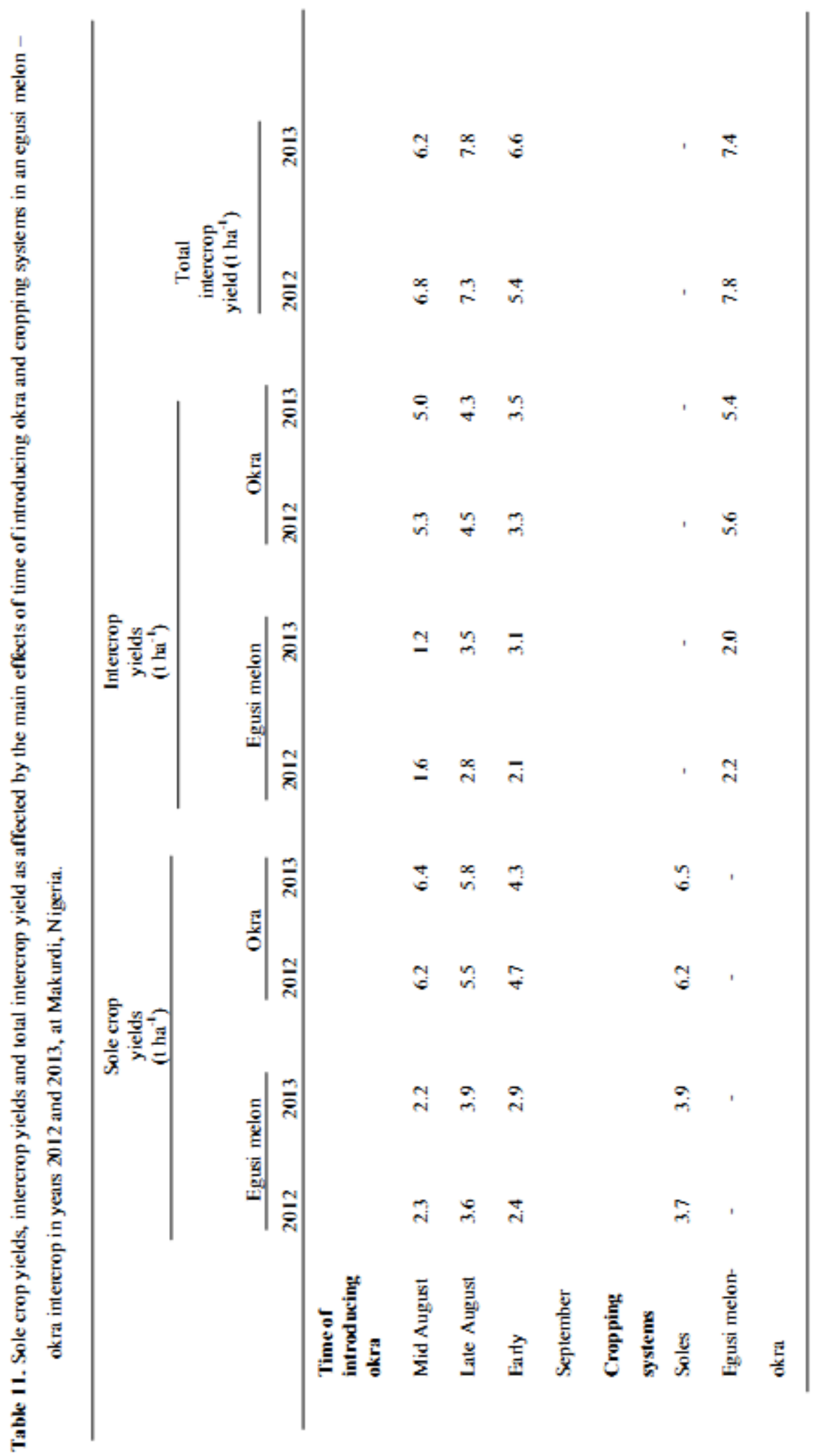




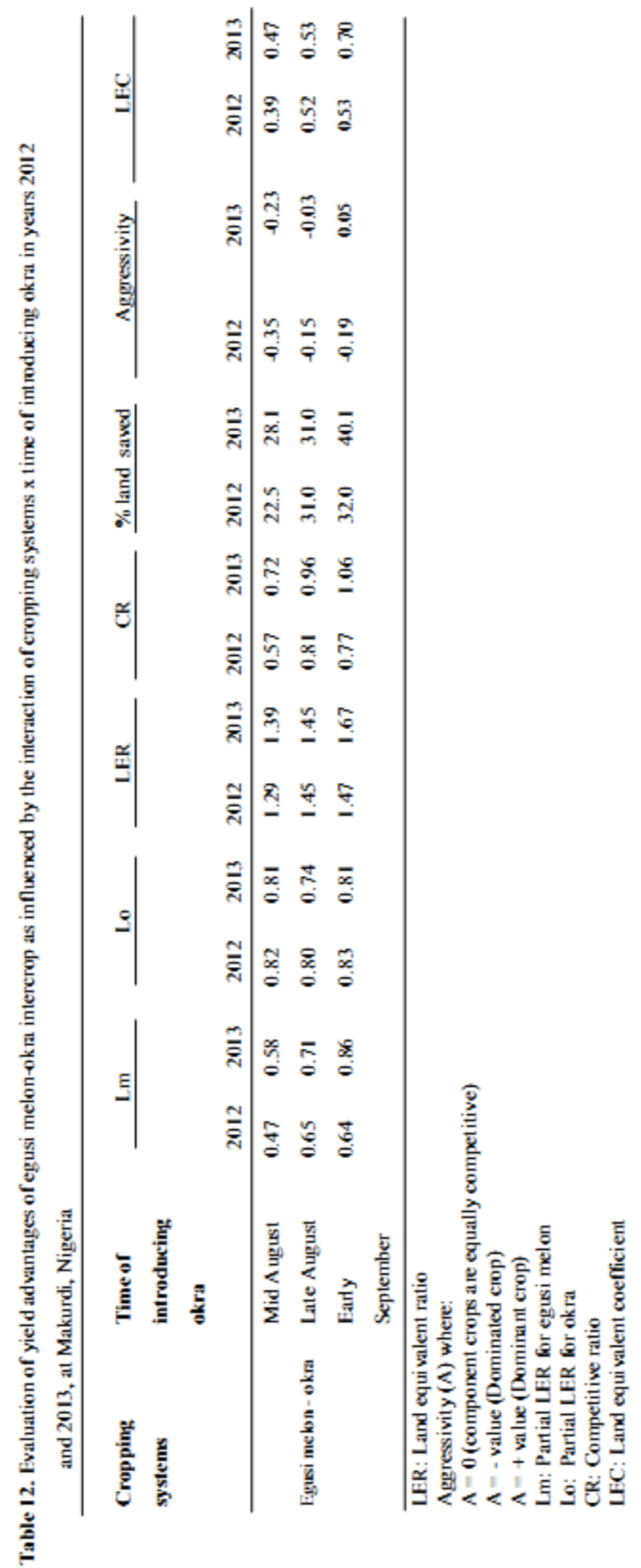




\section{References}

[1] Absar N., Siddique M.A., Bangladesh Journal of Agriculture 7 (3-4) (1992) 15-21.

[2] Adetiloye P.O., Ezedinma F.O.C., Okigbo B.N., Ecology Modelling 19 (1983) 27-39.

[3] Badifu G.I.O., Ogunsa A.O., Plant Foods and Human Nutrition 41 (1991) 35-44.

[4] Balock A.F. (1994). Vegetable Crops: Horticulture, National Book Foundation, Islamabad, pp. 529-531.

[5] BOSADP (1998). Cropping recommendations. Borno State Agricultural Development Programme, Annual Report, Pp. 76.

[6] Breda, N.J., Journal of Experimental Botany 54 (2003) 2403-2417.

[7] Brisibe E.A., Udensi O., Ntui V.O., Out P.A., Chukwurah P.N., African Journal of Plant Science 5(13) (2011) 759-766.

[8] Burkil H.M. (1997). The useful plants of tropical West Africa. $43^{\text {rd }}$ Ed., Royal botanical gardens, Kew, Pp. 166-179.

[9] Christo E.I., Onuh M.O. (2005). Influence of plant spacing on the growth and yield of okra (Abelmoschus esculentus (L) Moench) Proceedings of the $39^{\text {th }}$ conference of the Agricultural Society of Nigeria, Benin, 2005, pp. 51-53.

[10] Ekpete D.M., Nigerial Agricultural Journal 13 (2000) 96-102.

[11] Enwezor W.O.E., Udo J., Ajotade K.A. (1989). Fertilizer procurement and distribution, fertilizer use and management practice for crops in Nigeria. Savenda Publishers, Nsukka, Nigeria, pp. 25-28.

[12] Ezeakunne C.O. (2004). Large scale fruit and vegetable production in Nigeria. Extension Bulletin, Ahmadu Bello University, Zaria, P. 8.

[13] Ibeawuchi I.K., Natural Science 5(1) (2007) 46-49.

[14] Ijoyah M.O., Jimba J., Nigeria Journal of Biodiversity and Environmental Science 2(2) (2012) $38-44$.

[15] Ijoyah M.O., Alexander A., Fanen F.T., Agriculture and Biology Journal of North America (6) (2012) 1328-1332.

[16] Ijoyah M.O., Atanu S.O., Ojo S., Journal of Applied Biosciences 32 (2010) 2015-2019.

[17] Katung M.D., Kachina B.D. (2005). Time of partial defoliation and GA3 effects on growth indices and yield of okra (Abelmoschus esculentus (L.) Moench) Proceeding of the $39^{\text {th }}$ conference of the Agricultural Society of Nigeria, Benin, 2005, pp. 210-213.

[18] Madu F.O., Nwosu S.K. (2001). Effect of fertilizer and time of interplanting maize on the performance of yam-maize intercrop Proceedings of the $2^{\text {nd }}$ annual farming systems research and extension workshop in Southern Eastern Nigeria, Umudike, January 10-14, pp. 27-30.

[19] McGilchrist C.A., Biometrics 27 (1971) 659-671.

[20] Muoneke C.O., Ogwuche M.A.O., Kalu B.A., African Journal of Agricultural Research 2(12) (2007) 667-677.

[21] Muoneke C.O., Asiegbu J.E., Journal of Agronomy 179(3) (1997) 179-185.

[22] Ogbonna P.E., Obi I.U. (2010). Aspects of reproductive character of egusi melon. Proceedings of the $34^{\text {th }}$ annual conference of genetics society of Nigeria, 22-27.

[23] Okaka V.B., Remison S.U., Nigeria Agricultural Journal 30 (1999) 49-58.

[24] Olufajo O.O., Tropical Oil Seeds Journal 1 (1992) 27-33. 
[25] Shad K.K., Wahab A., Rehman A., Fida M., Wahab S., Khan A.Z., Zubair M., Mir K.S., Khalil I.H., Amin R., Pakistan Journal of Botany 42(6) (2010) 3831-3838.

[26] Silwana T.T, Lucas E.O., Journal of Agricultural Science 138 (2002) 193-200.

[27] Steel G.O., Torrie J.H. (1980). Principles and procedures of statistics. A biometrical approach. $2^{\text {nd }}$ edition, McGraw-Hill Book International Company, New York, Pp. 633.

[28] Tindal H.D. (1986). Vegetables in the tropics. $1^{\text {st }}$ edition, Macmillan Publishers, Hong Kong, pp. 325-327.

[29] Turk M.A., Tawaha A.M., El-Shatnawi A.A., Journal of Agronomy Crop Science 189(1) (2003) $1-6$.

[30] Usman S.D., Seed Research 29(1) (2001) 47-51.

[31] Willey R.W., Experimental Agriculture 21 (1985) 119-133.

[32] Willey R.W., Rao M.R., Experimental Agriculture 16 (1980) 117-125.

[33] Yadev S.K., Dhanker B.S., Vegetable Science 27 (2002) 70-74. 